\title{
EFFECT OF STEP PATTERN TECHNIQUE TO SIDE AND MOVEMENT STEP STRAIGHT AHEAD TO SABIT KICKNESS
}

\author{
Julianur $^{1}{ }^{*}$, Januar Abdilah Santoso ${ }^{2}$, Jeane Betty Kurnia Jusuf ${ }^{3}$, Andri Tria Raharja ${ }^{4}$, Nanda \\ Alfian Mahardhika ${ }^{5}$ \\ 1,2,3,4,5 Faculty of Education, Universitas Muhammadiyah Kalimantan Timur \\ Email: jul196@umkt.ac.id
}

\begin{abstract}
This study aims to determine the effect of exercise on stepwise pattern and exercise a straight forward move towards crescent kick agility in UKM PSHT students of Muhammadiyah University of East Kalimantan (UMKT). The population in this study were students who were still actively participating in the UKM PSHT UMKT. Sampling uses a random sampling system, divided into 2 groups, namely group A by practicing stepwise patterns and group B by practicing a straight forward step. Each group consists of 10 sample people, so the total sample is 20 people. The results showed that: (1) There was the effect of training the step-by-step pattern on crescent kick agility on UMKT PSHT UKM students who obtained the value of tcount $=9.531>$ $\mathrm{t}$ table $=2.262$ with a probability value of $0.000<\alpha 0.05$. (2) There is the effect of a straightforward exercise on crescent kick agility on UMKT PSHT UKM students who obtained a tcount $=6.975>\mathrm{t}$ table $=2.262$ with a significance probability value of $0.000<\alpha 0.05$. (3) There is a difference in the effect of step-to-side pattern training and straight-forward motion training on crescent kick agility in UKM PSHT UMKT students by obtaining a tcount $=4.348>\mathrm{t}$ table $=$ 1.734 with a significance probability value of $0.000<\alpha 0.05$.
\end{abstract}

Keywords: Martial arts, crescent kicks, psht

\section{INTRODUCTION}

Education is one of the main pillars in human development as a whole that serves to develop capabilities and can improve the life and dignity of the Nation and State. Education has pedagogical targets, therefore education is incomplete without physical and health education. Physical education and health are an integral part of education as a whole, aiming to develop aspects of physical fitness, movement skills, critical thinking skills, social skills, reasoning, emotional stability, moral actions, aspects of healthy lifestyles and the introduction of a clean environment through physical activity, exercise and health. 
The development of sports in Indonesia, especially in each sport requires serious guidance, especially the martial arts pencak silat, currently the martial arts sport is in great demand by students, students and the general public. Pencak silat is a martial art that uses elements of defense and attack that are fending / dodging, regarding / attacking on targets and dropping opponents, using tactics and techniques, endurance stamina and fighting spirit, using rules and step patterns that utilize a wealth of techniques to get value.

Among the students of Pencak Silat martial arts are very popular proof almost every university has a martial arts extracurricular activities, one of which is in the activity unit of PSHT University of Muhammadiyah East Kalimantan (UMKT), enthusiastic attitude of students is very good and very supportive to be maintained and developed as habits and hobbies exercise.

The attitudes, habits and hobbies of sports have indeed been owned by the Indonesian people since time immemorial, especially sports that are short-lived like martial arts. A variety of martial arts streams grew very fertile among Indonesians. Similar sports are well received in the community, as is the case with martial arts pencak silat. Pencak silat in addition to self-defense, can also be used as a means to exercise, because in pencak silat required to move the whole body, and in pencak silat will be able to encourage / stimulate the physical and mental strength of every human being. There are several basic techniques in pencak silat that must be known, namely: punch techniques (front, pendulum / swing target heart or chin, side, elbow, prick, totokan, grip etc.), kick techniques (front, sickle, "T" side , circle / round, reverse and cutout), the technique is viewed from the step motion, steps include (straight motion: can be forward or backward, sideways, stepped steps, forward cross motion, backward motion, and motion rotary step).

According to Johansyah Lubis (2003: 7), the basic technique of pencak silat is a planned, directed, coordinated, and controlled movement, which has four aspects as a whole, namely mental spiritual aspects, martial aspects, sports aspects and cultural arts aspects. Thus, it is a sport that is complete enough to be studied because it has four aspects which are a whole unit and cannot be separated. The technique movement in pencak silat is a series of complex moves that are relatively difficult for beginners. For that, at the beginning of each lesson, the movement must be given gradually and continuously. This means that the learning process starts from the easy to the difficult and from the simple to the complex. While from the notion of neatness technique value is an additional value for the fighter, to play in the rules or provisions of a good and right match. Neatness techniques include: the attitude of pairs and variations in pairs, steps and correct step patterns, good coordination when carrying out attacks and defenses, always re- 
pairs when carrying out attacks or defenses (Joko Subroto \& Moch. Rochadi, 1996: 71). In addition, technique is the most efficient and simple way to solve physical obligations or problems encountered in a match that is justified by regulations (Thomson, 1991: 49).

In the step pattern, the step is the technique of footwork in moving and changing positions to approach or stay away from the opponent in order to get a better or advantageous position that is combined and coordinated with the posture and hand attitude (PB IPSI Training Institute, 2002: 5). Seen in the observations, the author saw many fighter who relied on one type of kick to get points from his opponents, among the types of kicks were one of them crescent kicks.

According to Johansyah Lubis (2004: 29), a crescent kick is a kick (c) whose trajectory is semicircular inward, with the dominant target of the side of the body and can be on all parts of the body, with the back of the foot or foot and usually a mainstay kick to look for points in the match because they have good speed at the time of the attack treatment with the legs.

In the rules for the formation of pencak silat movements, the notion of motion is the movement of attitudes from one position to another, to do defense or attack. In order for an effective pencak silat movement as a strike movement, it needs to be shaped according to the right methods. The formation of the pencak silat movement includes four elements, namely: direction, step, shape / pattern of steps and how to move (Joko Subroto \& Moch. Rochadi, 1996: 24).

But the observations of the authors in the survey in the Student Activity Unit of PSHT University of Muhammadiyah East Kalimantan, especially in the development of martial arts martial arts talents as an achievement sport as well as the physical freshness of PSHT pencak silat students and observing student movements are still lacking in all forms of techniques and movements. One of them is when doing sickle kicks with avoidance techniques using movements and steps. Because when doing sickle kicks using motion and step techniques, many do sickle kicks slowly which results in a less than optimal training process and the kicks are not formed optimally as expected. And when doing a sickle kick there are still many students who kick in all directions, not in accordance with the target when viewed from the agility of the movement without using the object or target.

To increase the agility of the sickle kick, we need to do some training techniques, including increasing the agility of the sickle kick, the need to treat the movement of the step pattern. Steps are changes to the feet to change the position of the body, both efforts to approach the opponent, avoid, attack / just to find the position / position that is most appropriate for the 
opponent (Joko Subroto \& Moch. Rochadi, 1996; 25). Among them is the technique of step-bystep pattern technique and straight forward moves. The stepwise pattern is the movement that is done with the initial attitude of the foot open shoulder width / the initial stance of the horses and moving to the left and right side. The importance of the step aside according to Joan M. Nelson (2001: 49) in some situations, the attacker stands between the victim and the way to pass himself. The sideways step gives the victim the chance to move away from the attacker and approach the exit. Whereas a straight forward move is a movement carried out with the initial attitude of the position of the first leg in front and one of them is behind the parallel and the direction of its motion goes forward and back back to the position of the initial position.

The reason the author took a step pattern became the main basis as a technique in the research that will be carried out in order to increase agility on sickle kicks, because it can be seen from the supporting factors of using the pattern pattern techniques, one of which is: 1) easy to do where when carrying out an attack on the limbs it can be combined easily, then a kick can provide a greater amount of support for the target or object chosen as a tool used to correct the movement of the attack on the limbs, 2) steps can also relieve a movement attacks on the limbs, even though the body position is in a simple tide state, 3) the advantage of the step pattern can also provide balance to the body, especially if the steps are used for kicks, and can also be a maximum avoidance when the opponent attacks.

Based on the explanation that has been described, the researcher is interested in researching pencak silat sports with the title "The Effect of the Technique of Accidental Step Patterns and Straight-Step Motion Forward on the Agility of the Crescent Kick" in the Activity Unit of PSHT University of Muhammadiyah East Kalimantan Students ".

This research is expected to be able to improve the crescent kick agility in the Student of PSHT UKM East Muhammadiyah University. The technique used by the writer chooses based on the relation between crescent kick agility which is an inseparable linkage.

\section{METHOD}

\section{A. Type of Research}

This type of research uses a type of field experimental research, in the sense of conducting treatment activities to see a result that will enforce casual between the variables studied.

\section{B. Variable and Research Design}

1. Research Variables 
The research variable is the nature to be examined from the prepared sample. The variables to be examined in this study are as follows :

a. Independent variable :

1) Practice the step-by-side pattern technique

2) Practice straight forward motion

b. Dependent variable: crescent kick agility

\section{Research design}

Because this research is a field experiment research, the research design used is "Randomized Pretest-Posttest Design". The design of this study can be described as follows :

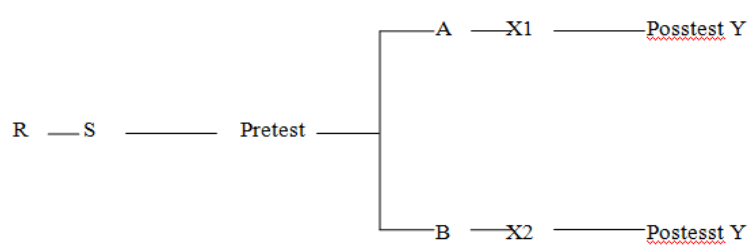

Figure 1 Design of the research design

Source: Sudjana (1985: 18)

Information:

$\mathrm{R} \quad=$ Randomized desain research

$\mathrm{S} \quad=$ Sample

Pretest $=$ Initial test

A $\quad=$ Group A (technical training step to side pattern)

B = Group B (practice straight forward moves)

$\mathrm{X} 1=$ Practice the technical training step pattern to the side

X2 = Treat the technical exercises in a straight forward step

Posttest $=$ Final test

$\mathrm{Y} \quad=$ Sickle kick agility

\section{Population and samples}

1. Population

Population is a collection or group of individuals that can be observed by members of the population itself or for people who have attention to it. Population is the whole subject of research (Arikunto, 2010: 173). Population gives a limit (scope) to the object to be studied. 
According to Sugiyono (2010: 61) the population is a region of generalization consisting of objects / subjects that have certain qualities and characteristics determined by researchers to be studied and then conclusions drawn.

Based on the opinions of the experts above, the population of this study were all students who were still actively taking part in the training in the 20 (twenty) people of the Muhammadiyah University of East Kalimantan PSHT.

2. Sample

Samples are partially or representative of the population studied. According to Sugiyono (2010: 62) the sample is part of the number and characteristics possessed by the population.

The following is given a table of determining the number of samples of a particular population developed from Isaac and Michael, for error rates, $1 \%, 5 \%$, and $10 \%$. The formula for calculating sample size from an unknown population is as follows:

$$
s=\frac{\lambda^{2} \cdot N \cdot P \cdot Q}{d^{2}(N-1)+\lambda^{2} \cdot P \cdot Q}
$$

Which is :

with $\mathrm{dk}=1$, the error rate can be $1 \%, 5 \%, 10 \% . \mathrm{P}=\mathrm{Q}=0.5 ; \mathrm{d}=0.05 ; \mathrm{s}=$ number of samples

The way to determine the sample is to use a random sampling technique. Thus the sample in this study was 20 students who were still actively participating in the UMKT Pencak Silat UKM. Of the 20 students selected to be the research sample, then divided into two groups. Regarding the research group, it was formed on the basis of the test results, namely the crescent kick agility test. The results are arranged by rank then divided into two groups that are balanced or commonly called machid ordinate. In this case it can be described as follows:

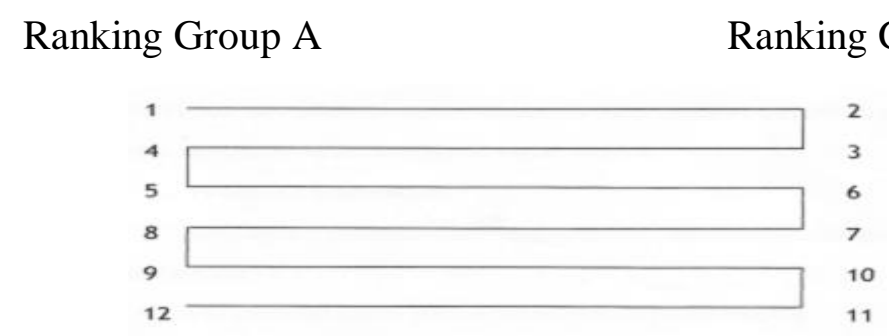

and so on, to how many members of the sample group are desired.

Group $A=10$ people

Group B = 10 people

\section{Data Collection Technique}


The data obtained must be reliable. For this reason, data collection techniques must be carried out as well as possible. This section is a research procedure used to obtain data relating to the existence of research variables.

1. Sickle kick agility test

a. Source: PB IPSI Training Institute (2002: 36).

b. Directions for assessment: the best trial results for the kick agility test are the test results.

c. Evaluation norms

Azwar (2004:54) states that to find out the tendency of observations of each variable, the division is into five categories using the benchmark as in the following table :

Table 1 Formulation of categories of distribution of sickle kick agility scores (Source: Azwar, 2004)

\begin{tabular}{|c|l|}
\hline \multicolumn{1}{|c|}{ Interval } & Criteria \\
\hline$\mu+1,5 \sigma<X$ & Very High \\
\hline$\mu+0,5 \sigma<X \leq \mu+1,5 \sigma$ & High \\
\hline$\mu-0,5 \sigma<X \leq \mu+0,5 \sigma$ & Is \\
\hline$\mu-1,5 \sigma<X \leq \mu-0,5 \sigma$ & Low \\
\hline$X \leq \mu-1,5 \sigma$ & Very Low \\
\hline
\end{tabular}

Information :

$\mu=$ mean $\quad \sigma=$ standard deviation

The best kick trial result is then reformulated to get the value and to get the value the writer uses the T-Scale table the ability of the martial arts martial arts pencak silat.

2. Training material

The training material that was experimented on was a stepwise pattern exercise technique for groups A and practicing straight forward for group B. each group was given training 3 times a week.

a. Heating

This heating is carried out for 15 minutes consisting of: stretching, running, and dynamic gymnastics. This heating aims to increase body temperature, prevent injury, improve blood circulation throughout the body, improve movement and reduce muscle tension in the face of this exercise.

b. Core Training

The core exercise is carried out for 45 to 50 minutes consisting of giving the treatment a step pattern sideways, moving forward straight and practicing adaptation to the crescent kick 
movement. The core training given to the experimental group with group A is a form of technical training of the step pattern aside and group B is the straight-forward step.

\section{E. Data analysis technique}

The data on the effect of step-by-step pattern technical training and the practice of straight forward moves and crescent kick agility on students of the Muhammadiyah University of East Kalimantan PSHT will be the authors of the analysis by using an analysis test in the form of a ttest with the formula :

1. Descriptive statistics, provide an overview of the results of the average standard deviation of the variables from the two groups.

2. Inferential statistics, test the hypotheses of the studies using the t-test at a significant level of $5 \%$. The t-test for calculating the mean difference between the initial test and the final test for the two groups is different from the formula.

$$
t=\frac{m d}{\sqrt{\frac{\sum x d^{2}}{n(n-1)}}}
$$

Information :

$\mathrm{T} \quad$ : Difference statistics

md : The mean of the difference in pre test and post test

$\sum x d^{2}:$ Total squared deviation

Error! Reference source not found. : : Number of samples

Calculation of differences in the second influence

$$
t=\frac{x A_{2}-x B_{2}}{\sqrt{\left(\frac{(S d A)-(S d B)^{2}}{n A+n B-2}\right)\left(\frac{1}{n A}+\frac{1}{n B}\right)}}
$$

Information :

$\mathrm{xA} \quad$ : the average technical training group steps to the side pattern

$\mathrm{xB} \quad$ : The average group exercise moves straight ahead

Sd A : The standard deviation of the technical training group is the step-to-side pattern

Sd B : The group standard deviation exercises a straight forward step

n : Number of samples 


\section{FINDINGS AND DISCUSSION}

Results should be clear and concise. The results should summarize (scientific) findings rather than providing data in great detail(Ahmadjayadi, 2017). Please highlight differences between your results or findings and the previous publications by other researchers.

Tables and Figures are presented center, as shown below and cited in the manuscript.

Table 1. Labor Regulations Subjects

\begin{tabular}{|c|c|c|c|}
\hline $\begin{array}{l}\text { Labor agreement } \\
\text { (Article 1/14 Act } \\
\text { 13/2003) }\end{array}$ & $\begin{array}{l}\text { Labor } \\
\text { relationship } \\
\text { (Article 1/15 Act } \\
\text { 13/2003) }\end{array}$ & $\begin{array}{l}\text { Industrial } \\
\text { relationship } \\
\text { (Article 1/15 Act } \\
\text { 13/2003) }\end{array}$ & $\begin{array}{l}\text { Industrial relation of } \\
\text { dispute } \\
\text { (Article } 1 / 15 \text { Act 13/2003 } \\
\text { jo. Article } 56 \text { Act No. } \\
\text { 2/2004) }\end{array}$ \\
\hline $\begin{array}{l}\text { 1. Worker } \\
\text { 2. Entrepreneur } \\
\text { 3. Employer }\end{array}$ & $\begin{array}{l}\text { 1. Entrepreneur } \\
\text { 2. Worker }\end{array}$ & $\begin{array}{l}\text { 1. Entrepreneur } \\
\text { 2. Worker } \\
\text { 3. The government }\end{array}$ & $\begin{array}{l}\text { 1. Entrepreneur-worker } \\
\text { 2. Entrepreneurs- } \\
\text { workers } \\
\text { 3. Entrepreneur- trade } \\
\text { union } \\
\text { 4. Entrepreneurs-trade } \\
\text { union } \\
\text { 5. trade union-trade union }\end{array}$ \\
\hline
\end{tabular}

The discussion should explore the significance of the results of the work, not repeat them. A combined Results and Discussion section is often appropriate. Avoid extensive citations and discussion of published literature.

In discussion, it is the most important section of your article. Here you get the chance to sell your data. Make the discussion corresponding to the results, but do not reiterate the results. Often should begin with a brief summary of the main scientific findings (not experimental results)(Handoko, 2014). The following components should be covered in discussion: How do your results relate to the original question or objectives outlined in the Introduction section (what)? Do you provide interpretation scientifically for each of your results or findings presented (why)?(N. S. B. of Indonesia, 2000) Are your results consistent with what other investigators have reported (what else)? Or are there any differences?

Writing using a separation section with numbers. The separation between Title, SubTitle, Sub-Title Children conducted by Using lowercase letters beginning with a capital letter, typed bold. 12pt Times New Roman, 1.5 space. Using Arabic numerals in the following example(Salam, 2013): 
Level 1: 2. Discussion

Level 2: 2.1 Education

Level 3: 2.1.1 Concept of Education

Level 4: 2.1.1.1 Concept of Education in England

\section{Result and Discussion}

\section{A. Result}

After collecting research data on the study sample, it will then be analyzed using Descriptive Analysis formulas, Kolmogorov Smirnov Test, Homogeneity of Samples, Paired Sample t-tests, and Independent Sample t-tests can be presented as follows.

\section{1) Descriptive Data Analysis}

Based on the results of the pre-test and post-test group A, crescent kick agility was found as follows.

Table 2: Results of Descriptive Analysis of Group A Side Step Pattern Exercises

\begin{tabular}{cccccccc}
\hline Group A & $\mathrm{N}$ & Mean & Std. Deviation & Variance & Max & Min & Range \\
\hline Preliminary Test & 10 & 11.0740 & 1.73077 & 2.996 & 14.22 & 8.77 & 5.45 \\
Final Test & 10 & 6.1280 & .58685 & .344 & 7.10 & 5.27 & 1.83
\end{tabular}

The table above shows the average calculation, standard deviation, the highest time variance, the lowest time and the range of the initial test scores and the final test of sickle kick agility in the Muhammadiyah University of East Kalimantan PSHT Student Training Group in the Step-by-Side Pattern exercise. In the training group the step pattern aside from the initial test score was 11.0740 points, the standard deviation was 1.73077 points, the standard deviation was 2.996 points and the fastest time in the crescent kick was 8.77 points and the lowest time was the sickle kick of 14.22 points so that time was obtained between the highest time reduced by the lowest time doing a sickle kick of 5.45 points. Whereas in the final test score the exercise group on the side step pattern obtained an average of 6.1280 points, the standard deviation of .58685 points, the standard deviation square of .344 points and the fastest time to do a sickle kick of 5.27 points and the lowest time of sickle kick of 7.10 points so that obtained the time between the highest time is reduced by the lowest time to do a sickle kick of 1.83 points. 
Table 3 Results of Descriptive Analysis of Group B Motion Exercises Straight Steps Forward

\begin{tabular}{cccccccc}
\hline Group B & $\mathrm{N}$ & Mean & Std. Deviation & Variance & Max & Min & Range \\
\hline Preliminary Test & 10 & 10.8000 & 1.80338 & 3.252 & 13.89 & 8.81 & 5.08 \\
Final Test & 10 & 7.4070 & .72160 & .521 & 8.83 & 6.74 & 2.09 \\
\hline
\end{tabular}

Based on the table above shows the average calculation, standard deviation, the highest value variance, the lowest value and the range of initial test scores and the final test of crescent kick agility in the Muhammadiyah University of East Kalimantan UKM PSHT students in the training group in a straight forward step. In the group of exercises the straight-forward movement of the initial test score obtained an average of 10.8000 points, the standard deviation was 1.80338 points, the standard deviation of 3,252 points and the fastest time to take a sickle kick was 8.81 points and the lowest time was sickle kicks of 13.89 points so that time was obtained between the highest time minus the lowest time to do a sickle kick of 5.08 points. Whereas in the final test score the group of straight-forward motion training obtained an average of 7.4070 points, standard deviation of .72160 points, standard deviation square of .521 points and the fastest time of crescent kicks of 6.74 points and the lowest time of sickle kicks of 8.83 points so that obtained the time between the highest time is reduced by the lowest time doing a sickle kick of 2.09 points.

\section{2) Data Analysis Requirements}

After the average value and standard deviation of the two groups of samples are known, then the next step is to test the normality of the data from the test results using the Kolmogorov Smirnov test. The goal is to establish a hypothesis testing technique that is if the data are normally distributed, then use a paired sample t-test and independent t-test and vice versa if the data are not normally distributed, then use non-parametric testing. The results of these tests can be seen in table four below.

Table 4 Testing Results of Kolmogorov Smirnov Group A

\begin{tabular}{cccc}
\hline Group Exercise A & Kolmogorov- Smirnov Z & Asym. Sig. (2-tailed) & Conclusion \\
\hline Beginning/end & $0.566 / 0.498$ & $0.906 / 0.965$ & Normal \\
\hline
\end{tabular}

Based on the table above shows that the results of this study obtained the KolmogorovSmirnov $\mathrm{Z}$ value of the initial test of 0.566 and the final test of 0.498 which was given the exercise of a step-to-side pattern. Asymp Value. Sig. (2-tailed) initial test 0.906 and final test 0.965. In accordance with the Asymp value testing criteria. Sig. (2-tailed) initial test 0.906 and final test 0.965 which was found to be greater than 0.05 significant level so that the research data 
could be said to be normal and parametric analysis techniques for paired sample t-tests could be carried out, so that testing the research hypothesis using parametric.

Whereas in the testing of kolmogorov smirnov in the training group, a straight forward movement can be seen in table five below.

Table 5 Testing Results of Kolmogorov Smirnov Group B

\begin{tabular}{cccc}
\hline Group Exercise A & Kolmogorov- Smirnov Z & Asym. Sig. (2-tailed) & Conclusion \\
\hline Beginning/end & $0.635 / 0.846$ & $0.815 / 0.472$ & Normal \\
\hline
\end{tabular}

Based on the table above shows that the results of this study obtained the value of the Kolmogorov-Smirnov $\mathrm{Z}$ initial test of 0.635 and final test of 0.846 which was given a straight forward motion exercise. Asymp Value Sig. (2-tailed) initial test 0,815 and final test 0,472. In accordance with the Asymp value testing criteria. Sig. (2-tailed) 0.815 initial test and 0.472 final test were found to be greater than 0.05 significant level so that the research data can be said to be normal and the parametric analysis technique of paired sample t-test can be performed, so testing the hypothesis of the research using the parametric approach.

And to find out homogeneous research data so that it can use parametric testing with independent t-test test techniques can be seen the results in the table below.

Table 6 Homogeneity Test Results

\begin{tabular}{c|ccccc}
\hline \multirow{2}{*}{$\begin{array}{c}\text { Agility kick } \\
\text { scythe }\end{array}$} & $\begin{array}{c}\text { Levene } \\
\text { Statistic }\end{array}$ & Df1 & Df2 & Sig. & Information \\
\cline { 2 - 6 } & 0.290 & 1 & 18 & 0.597 & Homogen \\
\hline
\end{tabular}

From the table above, it can be seen that the sig or probability value (0.597) is greater than 0.05 so that the data of this study are homogeneous or both have not been given an exercise that is training exercises step-to-side patterns and exercises in a straight forward step.

\section{3) Hypothesis testing}

\section{a. Test for Group A Paired Sample T Test}

After the data shows normal and homogeneous distributors, then the next step is to do testing and analysis of the two groups of sample data (testing and analysts to find out whether the differences in sickle kick results are significant from the two sample groups studied).

The first hypothesis to be tested :

$\mathrm{H}_{\mathrm{o}}: \mu_{1}-\mu_{2}=0$ opponent $\mathrm{H}_{1}: \mu_{1}-\mu_{2} \neq 0$

$\mathrm{H}_{\mathrm{o}}=$ There was no difference in the results of sickle kicks on the students of the Muhammadiyah University of East Kalimantan PSHT before being given a step-to-side pattern training and after being given a step-to-side pattern. 
$\mathrm{H}_{1}=$ There are differences in the results of sickle kicks on the students of the Muhammadiyah University of East Kalimantan PSHT before being given a training step-to-side pattern and after being given a training step-to-side pattern.

Table 7 A sickle kick agility calculation results

\begin{tabular}{c|ccc}
\hline Paired t-test & $\mathrm{t}_{\text {count }}$ & Sig. (2-tailed) & $\mathrm{t}_{\text {table } 0,05}$ \\
\cline { 2 - 4 } Group A & 9.531 & 0.000 & 2.262 \\
\hline
\end{tabular}

Based on the table above the research hypothesis that will be tested is rejecting Ho and accept $\mathrm{Ha}$ if $\mathrm{t}$-count $>\mathrm{t}$ table at a significant level $\alpha=0.05$ so that there is an effect of training step-by-side pattern on crescent kick agility in Student of PSHT UKM East Muhammadiyah University While accept Ho and reject Ha if $\mathrm{t}$-count $<\mathrm{t}$ table at a significant level $\alpha=0.05$ so that there is no effect of training the step pattern sideways towards crescent kick agility in the Student PSHT UKM Muhammadiyah University of East Kalimantan. And reject Ho and accept Ha, if Sig. (2-tailed) $<\alpha=0.05$ significant level so that there is an effect of exercise step-by-side pattern on crescent kick agility in UKM PSHT Students of Muhammadiyah University of East Kalimantan. Meanwhile accept Ho and reject Ha if Sig. (2-tailed) $>\alpha=0.05$ significant level so that there is no effect of the sideways training pattern on the agility of the sickle kick on the Student of UKM PSHT Muhammadiyah University of East Kalimantan. Based on testing the hypothesis about the effect of the sideways pattern exercise on the agility of the sickle kick on PSHT UKM Muhammadiyah University Students in East Kalimantan. In accordance with the hypothesis testing criteria, a decision of t-count value of 9.531 can be taken greater than ttable 2.262 so that $\mathrm{Ho}$ is rejected and $\mathrm{Ha}$ is accepted or it can be said that there is an effect of the sideways pattern exercise towards the agility of a kick kick in the Student of UKM PSHT Muhammadiyah University of East Kalimantan.

While testing the sig value obtained by Sig. (2-tailed) 0,000 is smaller than 0.05 so Ho is rejected and $\mathrm{Ha}$ is accepted.

The conclusion: It can be said that there is an effect of the exercise of a step-by-side pattern on the crescent kick agility in a significant student of the Muhammadiyah University of East Kalimantan PSHT.

\section{b. Test for Paired Sample T Test Group B}

After the data shows a normal and homogeneous distributor, the next step is to test and analyze the two groups of sample data (testing and analysis to find out whether the difference in the results of the sickle kick is significant from the two sample groups studied) 
The first hypothesis to be tested :

$\mathrm{H}_{\mathrm{o}}: \mu_{1}-\mu_{2}=0$ opponent $\mathrm{H}_{1}: \mu_{1}-\mu_{2} \neq 0$

$\mathrm{H}_{\mathrm{o}}=$ There was no difference in the results of sickle kicks on the UKM PSHT students of the East Kalimantan Muhammadiyah University before being given training in straightforward steps and after being given a straight-line exercise.

$\mathrm{H}_{1}=$ There is a difference in the results of a sickle kick on the students of UKM PSHT Muhammadiyah University of East Kalimantan before being given a straight-forward motion exercise and after being given a straight-forward motion exercise.

Table 8 Results of sickle kick Agility Calculation B

\begin{tabular}{c|ccc}
\hline Paired t-test & $\mathrm{t}_{\text {count }}$ & Sig. (2-tailed) & $\mathrm{t}_{\text {table } 0,05}$ \\
\cline { 2 - 4 } Group B & 6.975 & 0.000 & 2.262 \\
\hline
\end{tabular}

Based on the table above the research hypothesis that will be tested is rejecting Ho and accepting $\mathrm{Ha}$ if $\mathrm{t}$-count $>\mathrm{t}$-table at a significant level $\alpha=0.05$ so that there is an exercise effect in a straight-forward step towards crescent kick agility in UKM PSHT Muhammadiyah University East Kalimantan students. While accept Ho and reject $\mathrm{Ha}$ if $\mathrm{t}$-count $<\mathrm{t}$ table at a significant level $\alpha=0.05$ so that there is no effect of the exercise of a straight forward step towards crescent kick agility in students of the UKM PSHT Muhammadiyah University of East Kalimantan. And reject Ho and accept Ha, if Sig. (2-tailed) $<\alpha=0.05$ significant level so that there is an exercise effect in a straight-forward step towards crescent kick agility in UKM PSHT students of East Kalimantan Muhammadiyah University. While accept Ho and reject Ha if Sig. (2-tailed) $>\alpha=$ 0.05 significant level so that there is no effect of training in a straight-forward step towards crescent kick agility in UKM PSHT students of East Kalimantan Muhammadiyah University. Based on the testing of the hypothesis about the effect of training, a straight forward step towards crescent kick agility in the UKM PSHT students of East Kalimantan Muhammadiyah University. In accordance with the hypothesis testing criteria it can be decided that the value of t-count 6.975 is greater than t-table 2.262 so Ho is rejected and Ha is accepted or it can be said that there is an exercise effect straight forward towards crescent kick agility in the significant student of Muhammadiyah University of East Kalimantan PSHT. While testing the sig value obtained by the value of Sig. (2-tailed) 0,000 smaller than 0.05 so Ho is rejected and Ha is accepted.

It can be said that there is an exercise effect in a straight forward move towards crescent kick agility in the students of the UKM PSHT Muhammadiyah University of East Kalimantan. 


\section{B. Discussion}

Based on the results of research data collection on the sample given training then the data were analyzed by paired sample analysis techniques $t$ test and independent test using IBM SPSS 20 computer data processing program. After testing hypotheses obtained the influence of exercise step-to-side patterns and motion exercises a straight forward step towards crescent kick agility in significant Muhammadiyah University East Kalimantan PSHT students. Then the results of the study through testing the effect of the training of step-to-side patterns and training in a straight-forward step towards crescent kick agility in UKM PSHT students of East Kalimantan Muhammadiyah University. Then some explanations will be given below.

\section{1) Effect of Side Step Pattern Exercises on Agility of Sick Kicks in UKM PSHT Students of}

\section{East Kalimantan Muhammadiyah University}

The results of the first hypothesis test showed that there was a significant effect on the exercise of the sideways pattern of the crescent kick agility in the students of the East Kalimantan PSHT Muhammadiyah University. It is evident that the value of observations = 9.531> of the value of $\alpha$ table 0.05 . The results of this study indicate that the exercise of the sideways pattern given for two months to the students of Muhammadiyah University of East Kalimantan's PSHT UKM had a significant influence on the crescent kick agility, this can be explained because the training of step-to-side patterns aims to train the legs in particular leg strength when walking. This is as stated by Harsono (1988: 77) about the importance of muscle explosive power in sports activities, which states that muscle explosive power is a very important component to improve overall physical condition, explosive power is the ability of muscles that move maximum strength in time which is very fast in every sporting activity. Motion activities in this way really need good explosive power, especially the muscles of the legs, with enough strength students will be able to do sickle kicks correctly and on target. The sideways pattern training exercise is an exercise to train leg speed and explosive power when doing sickle kicks, especially when in contact with your opponent.

Thus it can be pointed out that the training of step-by-side patterns is an important element of step patterns and needs attention, especially in making training programs to improve the agility of student sickle kicks.

2) Influence of Motion Exercises Straight Steps Forward Against Agility of Sickle Kicks in UKM PSHT Students of Muhammadiyah University of East Kalimantan.

The second hypothesis test results show that there is a significant influence on the exercise of a straight-forward step towards crescent kick agility in UKM PSHT students of East 
Kalimantan Muhammadiyah University. It is evident that the value of observations $=6.975>$ of the value of t table $\alpha 0.05$. The results showed that the exercise of straight forward motion given for two months to the students of Muhammadiyah University of East Kalimantan's PSHT UKM had a significant influence on the crescent kick agility, it can be explained that the exercise of a straight forward motion aims to train the strength of the legs in when doing sickle kicks, especially the physical components of explosive legs. If someone has good leg strength, it will be easier to make a crescent kick when playing in a match and thus will increase the agility of the kick.

It can be explained that one of the physical abilities needed in the sport of Pencak Silat is speed and good explosive power that can produce agility in motion. Judging from the crescent kick movement pattern, a component of physical condition is needed such as speed and good limb explosive power. Speed (speed) is the ability of a person to work on continuous movements in the same form and in the shortest possible time.

A straight forward exercise is an exercise to train the speed of the legs, especially when doing motion activities. Seen in the effect of training straight-forward moves carried out for less than 2 months for students is the movement when making sickle kicks can be directly combined with the speed of avoidance and then make a sickle kick against the opponent. Thus the implication of this research is the importance of training the speed and good explosive power of the legs, by practicing a straight forward motion that increases the speed and explosive power of the muscles when doing sickle kicks.

\section{3) Differences in the Effect of Side-Step Pattern Exercises and Motion Exercises Straight Steps Forward Against Agility of Sick Kicks in UKM PSHT Students of Muhammadiyah University of East Kalimantan}

Then from the results of testing the data analysis there is a difference in the effect of stepto-side pattern training and straight forward exercise on crescent kick agility in the Muhammadiyah University of East Kalimantan PSHT UKM students, and training the step pattern to the side is better than practicing straight steps forward. It is proven that the tobesvasi value $=4.348>$ of the value of t table $\alpha 0.05$.

In the analysis of the movement and the stepping pattern of the two forms of training in this study did not show any significant differences, namely the practice of stepping patterns to the side of students doing one of the neutralizing techniques designed to thwart the attack. The neutralizing technique consists of several techniques, such as circumvention, breeding and releasing strangulation (Joan M. Nelson, 2001: 49). 
Whereas in a straight forward move the student takes steps which is a technique of footwork in transfer and a position modifier to approach and stay away from the opponent in order to get a better or advantageous position that is combined and coordinated with gestures and hands (PB IPSI coaches, 2002: 5). When viewed from the direction of straight forward motion, the movement can be done by stepping forward and backward by returning to the starting position of the front horse.

So that the results of this study can be used as a recommendation material for the martial arts sports coach SME PSHT Muhammadiyah University of East Kalimantan, that to improve the crescent kick agility exercise stepping pattern to the side and practicing straight forward moves can be used as part of a series of exercises that given in designing an exercise program created by a sports coach or coach.

\section{CONCLUSIONS}

Based on data analysis and discussion, the results of this study can be summarized as follows :

1) There is a significant influence on the exercise of the sideways pattern on the crescent kick agility in the Muhammadiyah University of East Kalimantan UKM Student.

2) There is the effect of training a straight forward step towards the crescent kick agility in a significant Student of Muhammadiyah University of East Kalimantan UKM PSHT.

3) There is a difference in the effect of the training of the step-to-side pattern and the exercise of a straight-forward step towards the crescent kick agility. The students of the Muhammadiyah University of East Kalimantan PSHT are significant.

\section{REFERENCES}

Akhmad. (2011). Metodologi Penelitian. Samarinda: Unpublished.

Arikunto, Suharsimi. (2009). Prosedur Penelitian. Jakarta: Rineka Cipta.

Arikunto, Suharsimi. (2010). Prosedur Penelitian. Jakarta: Rineka Cipta.

Cahyono, Didik. (2012). Pengaruh Latihan Beban Rumpi Kaki dan Beban Karet Terhadap Kemampuan Tendangan Sabit Atlet Silat PSHT Samarinda. Samarinda: Thesis not published.

Darmadi, Hamid. (2011). Metode Penelitian Pendidikan. Bandung: Alfabeta

Kosasih, Engkos. (1993). Olahraga. Jakarta: Akademika Pressindo

Lembaga Pelatihan PB IPSI. (2002). Pedoman Membina dan Melatih Pencak Silat. Jakarta: Unpublished 
Lubis, Johansyah. (2004). Pencak Silat Panduan Praktis. Jakarta: PT. Raja Grafindo Persada

Nelson, Joan M. (2001). Latihan Bela Diri Praktis. Jakarta: PT. Raja Grafindo Persada

Prawirasaputra,S., Lutan,R., \& Yusuf,U. (1999). Dasar-dasar Kepelatihan. Jakarta: Departemen Pendidikan dan Kebudayaan.

Subroto, Joko., \& Rochadi, Moch. (1996). Kaidah-kaidah Pencak Silat Seni Bela Diri. Solo: CV. Aneka

Sugiyono. (2010). Statistika untuk Penelitian. Bandung: Alfabeta 